\title{
IDENTIFICATION OF DIFFERENTIALLY EXPRESSED GENES IN AXILLARY TILLERS OF PERENNIAL RYEGRASS
}

\author{
Gintaras Brazauskas and Izolda Pašakinskienè \\ Lithuanian Institute of Agriculture, Akademija, Kèdainiai d., LT-58344, LITHUANIA \\ E-mail: gintaras@ @zi.lt.
}

Communicated by İzaks Rašals

\begin{abstract}
A PCR-based suppression subtractive hybridisation (SSH) technique was used to identify differentially expressed genes in the primary and axillary tillers of a perennial ryegrass (Lolium perenne L.) mutant with enhanced axillary tillering. A total of 310 expressed sequence tags (ESTs) were obtained representing 249 non-redundant sequences. The average EST sequence length was $249 \mathrm{nt}$ and varied from 30 to $508 \mathrm{nt}$. Putative function was assigned to 152 ESTs by comparing sequences with publicly available databases of NCBI. The remaining 97 ESTs had no sequence similarity matches to any of the known databases. Several ESTs were selected as potential candidates for the control of axillary tiller formation. RUB1 conjugating enzyme and BIG protein were shown to play role in auxin response regulation, SHOOT1 protein was associated with fasciation mutation in soybean (Glycine max L.), and brassinosteroid LRR receptor kinase with brassinosteroid signalling.
\end{abstract}

Key words: suppression subtractive hybridisation, perennial ryegrass, tillering.

\section{INTRODUCTION}

Lolium spp. are important forage and turf grasses, grown over a wide territory in Europe and used mainly as pasture, hay crop or ground cover. Perennial ryegrass (Lolium perenne L.) has a high yield of superior quality and fast establishment, but however, the persistency is moderate. One of the primary objectives in breeding for agricultural use is to improve axillary tillering to improve persistency of perennial ryegrass (Wilkins, 1991). Breeding for high yield has led to a tendency in modern perennial ryegrass genetic lines towards swards having a lower density of larger tillers. However, persistency of perennial ryegrass depends on the equilibrium between relative rate of tiller initiation and tiller death (Bahmani et al., 2000).

Plant architecture evolution has played a central role in the morphological diversification of plant species, although relatively little is known about its molecular basis. Only a small number of genes that control plant architecture have been identified (Ehrenreich et al., 2007), the best known example being the maize teosinte branched 1 (tbl) gene (Doebley et al., 1997). A TCP class transcription factor, $t b l$, is responsible for reduced tillering in maize, compared to that in teosinte (Clark et al., 2006). Developmental regulation of branching, one component of shoot architecture, occurs at several levels, including (i) node patterning, (ii) meristem determination, and (iii) axillary meristem elongation. Shoot branches arise from axillary shoot meristems, which form in the axils of leaves on the primary shoot axis (Ward and Leyser, 2004). Several genes are known to control node patterning, such as LATERAL SUPPRESSOR (LAS) (Greb et al., 2003) and SHOOT MERISTEMLESS (STM) (Long et al., 1996) in Arabidopsis thaliana. The meristem identity was shown to be determined by TERMINAL FLOWER 1 (TFL1) (Bradley et al., 1997) and branch elongation is regulated by numerous phytohormones, such as auxin, cytokinin, and abscisic acid (Ward and Leyser, 2004) as well as various hormone signalling genes, such as Auxin resistant 1 (AXRl) (Stirnberg et al., 1999).

Most of these genes were identified in model plant Arabidopsis thaliana and little is known about the molecular control of axillary tiller formation in forage grasses. In order to fill this gap in knowledge, a PCR-based suppression subtractive hybridisation ( $\mathrm{SSH}$ ) technique was used to identify differentially expressed genes in the primary and axillary tillers of perennial ryegrass mutant VIROIZ with enhanced axillary tillering.

\section{MATERIALS AND METHODS}

Plant material was collected from VIROIZ, a mutant of perennial ryegrass with enhanced axillary tillering (Pasakinskiene, 2005). Vegetative clones were grown in a peat : soil mixture of $1: 1$ in pots in a greenhouse. Plant material was collected at flowering stage from of primary and axillary tillers, frozen in liquid nitrogen and then kept at $-80{ }^{\circ} \mathrm{C}$. 
Frozen samples were ground in liquid nitrogen. Total RNA was isolated as described previously with minor modifications (Ausubel et al., 2002). The quantity and quality of the total RNA was examined by spectrophotometry and gel electrophoresis, respectively. mRNA was purified from the total RNA with Oligotex mRNA Midi Kit (QIAGEN). The concentration of mRNA was determined on Gene Quant II (Pharmacia). $2 \mu \mathrm{g}$ of mRNA was used for suppressive subtractive hybridisation with the Clontech PCR-Select cDNA Subtraction Kit (BD Biosciences Clontech). Forward- and reverse-subtracted cDNA fragments were inserted into TOPO PCRII vectors and transformed into TOP10 chemically competent E. coli cells (both Invitrogen). One hundred and ninety two cDNA clones were randomly selected from each of the forward and reverse SSH libraries. These clones, freshly grown overnight at $37{ }^{\circ} \mathrm{C}$, were used for plasmid isolation with Montage Plasmid Miniprep $_{\text {HTS }} 96$ Kit (Millipore). Three hundred ten plasmid inserts were sequenced with a MegaBACE 1000 automated capillary sequencer (Molecular Dynamics). Sequencing reactions were prepared with a DYEnamic ${ }^{\mathrm{TM}} \mathrm{ET}$ Dye Terminator Kit (GE Healthcare). The raw sequences were manually edited to remove vector and SSH adaptor fragments. These trimmed sequences were then annotated by performing sequence similarity searches against the NCBI nr database using the BLASTN programme with a cutoff e-value of $1 \times \mathrm{e}^{-5}$.

\section{RESULTS}

Forward and reverse subtractions were conducted using primary and axillary tillers of perennial ryegrass mutant VIROIZ. A total of 310 expressed sequence tags (ESTs) were obtained (Table 1). The average EST sequence length were $249 \mathrm{nt}$ and varied from 30 to $508 \mathrm{nt}$. Sequences obtained from forward subtraction were in general slightly shorter than sequences from reverse subtraction, 227 and $268 \mathrm{nt}$, respectively. Sequence analysis identified 249 non-

Table 1

EFFICIENCY OF FORWARD AND REVERSE SUBTRACTIVE HYBRIDISATION (SSH)

\begin{tabular}{l|c|c|c|c}
\hline \multicolumn{1}{c|}{ SSH } & $\begin{array}{c}\text { ESTs } \\
\text { obtained }\end{array}$ & $\begin{array}{c}\text { Non- } \\
\text { redundant } \\
\text { ESTs }\end{array}$ & $\begin{array}{c}\text { ESTs with } \\
\text { putative } \\
\text { function }\end{array}$ & $\begin{array}{c}\text { Length of ESTs, } \\
\text { nt average } \\
\text { (range) }\end{array}$ \\
\hline Forward & 148 & 126 & 57 & $227(71-508)$ \\
Reverse & 162 & 123 & 95 & $268(30-482)$ \\
Total & 310 & 249 & 152 & $249(30-508)$
\end{tabular}

ESTs, expressed sequence tags redundant sequences and the rest 61 ESTs with multiple copies. Only a few ESTs had three or four copies in the library while the majority of the redundant sequences were represented by only two copies. The level of redundancy between forward and reverse subtracted libraries was very low. Only one sequence assigned as "ADP-ribosylation factor" (GenBank NP_196971.1) was present in both forward and reverse subtractions as double copies, LIA144, LIA147 and LIA423, LIA425, respectively.

Putative function was assigned to 152 ESTs by comparing sequences with publicly available databases of NCBI. The remaining 97 ESTs had no sequence similarity matches to any of the known databases. 57 forward subtraction and 95 reverse subtraction sequences were assigned to putative function. Several ESTs were selected as potential candidates for the control of axillary tiller formation (Table 2). RUB1 conjugating enzyme (AF469491) and BIG protein (NP_186875) were shown to play a role in auxin response regulation, SHOOT1 protein (AF349572) with fasciation mutation in soybean (Glycine $\max$ L.), and brassinosteroid LRR receptor kinase (BAC07439) in brassinosteroid signalling.

\section{DISCUSSION}

Several techniques are available for isolation of differentially expressed genes: differential display (Liang and Pardee, 1992), enzymatic degradation subtraction (Zeng et al., 1994), representational difference analysis (RDA) (Lisitsyn et al., 1993) and serial analysis of gene expression (SAGE) (Velculescu et al., 1995). In this study, we chose a PCRbased suppression subtractive hybridisation ( $\mathrm{SSH}$ ) technique, which has been shown to be both simple and efficient for generating cDNAs highly enriched for differentially expressed genes of both high and low abundance (Diatchenko et al., 1996). The efficiency of SSH can be evaluated by its ability to identify non-redundant and, more importantly, differential sequences between samples. Ji et al. (2002) have suggested an assumption, based on a theoretical model of $\mathrm{SSH}$, that SSH PCR would be highly ineffective in profiling gene expression changes where small changes in gene expression are more likely to be physiologically relevant. They calculated that the target mRNA must be at least $0.1 \%$ of the total mRNA for effective enrichment by SSH PCR, and thus, genes in low abundance, such as transcription factors, cytokines and receptors, would not be detected by this method (Ji et al., 2002). However, it was shown earlier, that a 1,000- to 5,000-enrichment for rare (several molecules per cell) cDNAs can be achieved in a single

SIMILARITY SEARCHES FOR CLONES OBTAINED BY SUBTRACTIVE HYBRIDISATION ON THE PRIMARY/AXILLARY TILLERS

\begin{tabular}{cccccc|c|c}
\hline Clone & Name & Size & Subtraction & Accession & Species & Eutative function \\
\hline 1 & LIA106 & 275 & Forward & AF469491 & Triticum aestivum & RUB1 conjugating enzyme \\
2 & LIA310 & 390 & Reverse & NP_186875 & Arabidopsis thaliana & Auxin transport protein $($ BIG $)$ \\
3 & LIA517 & 345 & Reverse & BAC07439 & Oryza sativa & Brassinosteroid LRR receptor kinase \\
4 & LIA526 & 243 & Reverse & AF349572 & Glycine max & Outgrowth of axillary buds $($ SHOOT1 protein $)$ & $2 \times 10^{-9}$ \\
& & & & & &
\end{tabular}


round of SSH procedure (Diatchenko et al., 1996). In our study $80 \%$ (249 out of 310) of ESTs obtained were nonredundant. Only a few ESTs had three or four copies in the library, while the majority of redundant sequences were represented by only two copies. Furthermore, forward and reverse SSHs were very "accurate" in identification of differentially expressed genes. Only one sequence, assigned as "ADP-ribosylation factor" (GenBank NP_196971.1), was present in both forward and reverse subtractions. Similar results were obtained in other experiments where only one of 62 subtracted clones represented redundant sequences (Diatchenko et al., 1996).

In flowering plants, the shoot apical meristem (SAM) is ultimately responsible for post-embryonic development of the primary shoot architecture. However, lateral meristems also play an important role in determining the final morphology of the above-ground part of the plant. The activity of lateral meristems is controlled by a wide range of developmental, environmental and genetic factors, where phytohormone signalling plays a central role in mediating these factors (Leyser, 2003).

The role of auxin in inhibiting shoot branching is well known. A major site for auxin synthesis is at the primary shoot apex, from which it is transported down the plant in the polar transport stream. Auxin moving in this way inhibits shoot branching (Ljung, 2001). We have identified two genes involved in auxin signalling in other species. RUB1 conjugating enzyme (AF469491) was shown to be involved in auxin-controlled gene expression in Arabidopsis thaliana. This enzyme is part of the Aux/IAA complex and acts as a key component of the ubiquitin-mediated proteolytic pathway (Kepinski and Leyser, 2002). The second gene (NP_186875), named $B I G$, encodes auxin transport protein which is also involved in cytokinin, gibberellin, abscisic acid, ethylene and brassinosteroid signalling (Kanyuka et al., 2003). Brassinosteroid LRR receptor kinase (BAC07439) from Oryza sativa was one more gene from brassinosteroid signaling pathway identified in SSH library. Brassinosteroids have a wide spectrum of physiological effects, including promotion of cell elongation and division, enhancement of tracheary element differentiation, retardation of abscission, enhancement of gravitropicinduced bending, promotion of ethylene biosynthesis, and enhancement of stress resistance, as reviewed by Clouse and Sasse (1998). Mutant plants that are defective in BR biosynthesis or signaling display characteristic phenotypes including dwarfism, curled leaves, male sterility, and light-grown morphology in the dark (He et al., 2005). SHOOT1 protein (AF349572) has also been shown to be associated with abnormal shoot development in soybean (Glycine max). It was mapped to the locus responsible for fasciation mutation, which causes strong apical dominance in the mutant and suppresses development of axillary buds and forms a branchless phenotype. Floral production occurs at the shoot apices and results in a pod-set pattern resembling cauliflower (Karakaya et al., 2002).
A large number of the genes involved in axillary tiller formation in this study encode unknown proteins, indicating that further analysis is required to assign putative functions to these genes. The derived ESTs are included in the set of 4224 cDNAs to produce the Lolium perenne derived cDNA microarray. Microarray hybridisations will be further employed to study control of axillary tiller formation in perennial ryegrass.

\section{ACKNOWLEDGEMENTS}

This study was conducted in the frame of the EU Framework V project GRASP (QLRT-2001-00862).

\section{REFERENCES}

Wilkins, P.W. (1991). Breeding perennial ryegrass for agriculture. Euphytica, 52(3), 201-214.

Bahmani, I., Hazard, L., Varlet-Grancher, C., Betin, M., Lemaire, G., Matthew, C., Thom, E.R. (2000). Differences in tillering of long- and short-leaved perennial ryegrass genetic lines under full light and shade treatments. Crop Sci., 40, 1095-1102.

Ehrenreich, I.M., Phillip, A.S., Purugganan, M.D. (2007). The genetic architecture of shoot branching in Arabidopsis thaliana: A comparative assessment of candidate gene associations vs. quantitative trait locus mapping, Genetics, 176, 1223-1236.

Doebley, J., Stec, A., Hubbard, L. (1997). The evolution of apical dominance in maize. Nature, 386, 485-488.

Clark, R.M., Wagler, T.N., Quijada, P., Doebley, J. (2006). A distant upstream enhancer at the maize domestication gene $t b 1$ has pleiotropic effects on plant and inflorescent architecture. Nat. Genet., 38, 594-597.

Ward, S.P., Leyser, O., (2004). Shoot branching. Curr. Opin. Plant Biol., 7, 73-78.

Greb, T., Clarenz, O., Schafer, E., Muller, D., Herrero, R. Schmitz, G., Theres, K. (2003). Molecular analysis of the LATERAL SUPPRESSOR gene in Arabidopsis reveals a conserved control mechanism for axillary meristem formation. Genes Dev., 17, 1175-1187.

Long, J.A., Moan, E.I., Medford, J.I., Barton, M.K. (1996). A member of the KNOTTED class of homeodomain proteins encoded by the STM gene of Arabidopsis. Nature, 379, 66-69.

Bradley, D., Ratcliffe, O., Vincent, C., Carpenter, R., Coen, E. (1997). Inflorescence commitment and architecture in Arabidopsis. Science, 275, 80-83.

Stirnberg, P., Chatfield, S.P., Leyser, H.M. (1999). AXR1 acts after lateral bud formation to inhibit lateral bud growth in Arabidopsis. Plant Physiol., 121, 839-847.

Pasakinskiene, I. (2005). "Creeping stem" mutation in L. perenne. In: Recent Advances in Genetics and Breeding of the Grasses (pp. 209-213). Zwierzykowski, Z., Kosmala, A. (eds.) Poznan: Institute of Plant Genetics PAS.

Ausubel, F.M., Brent, R., Kingston, R.E., Moore, D.D., Seidman, J.G., Smith, J.A., Struhl, K. (eds.). (2002). Short Protocols in Molecular Biology. Wiley, USA.1024 pp.

Liang, P., Pardee, A.B. (1992). Differential display of eukaryotic messenger RNA by means of the polymerase chain reaction. Science, 257, 967-971.

Zeng, J., Gorski, R.A., Hamer, D. (1994). Differential cDNA cloning by enzymatic degrading subtraction (EDS). Nucleic Acids Res., 22, 4381-4385.

Lisitsyn, N., Lisitsyn, N., Wigler, M. (1993). Cloning the differences between two complex genomes. Science, 259, 946-780.

Velculescu, V.E., Zhang, L., Vogelstein, B., Kinzler, K.W. (1995). Serial analysis of gene expression. Science, 270, 484-487. 
Diatchenko, L., Lau, Y.F., Campbell, A.P., Chenchik, A., Moqadam, F., Huang, B., Lukyanov, S., Lukyanov, K., Gurskaya, N., Sverdlov, E.D., Siebert, P.D. (1996). Suppression subtractive hybridization: A method for generating differentially regulated or tissue-specific cDNA probes and libraries. Proc. Natl. Acad. Sci. U S A, 93, 6025-6030.

Ji, W., Wright, M. B., Cai, L., Flament, A., Lindpaintner, K. (2002). Efficacy of SSH PCR in isolating differentially expressed genes. BMC Genomics, $\mathbf{3}$, 12 .

Leyser, O. (2003). Regulation of shoot branching by auxin. Trends in Plant Sci., 8(11), 541-544.

Ljung, K., Bhalerao, R.P., Sandberg, G. (2001). Sites and homeostatic control of auxin biosynthesis in Arabidopsis during vegetative growth. Plant $J ., 28,465-474$.

Received 10 October 2007
Kepinski, S., Leyser, O. (2002). Ubiquitination and auxin signaling: A degrading story. The Plant Cell, 14 (suppl.), S81-S95.

Kanyuka, K., Praekelt, U., Franklin, K.A., Billingham, O.E., Hooley, R., Whitelam, G.C., Halliday, K.J. (2003). Mutations in the huge Arabidopsis gene $B I G$ affect a range of hormone and light responses. Plant $J ., 35,57-70$.

Clouse, S.D., Sasse, J.M. (1998). Brassinosteroids: Essential regulators of plant growth and development. Annu. Rev. Plant Physiol. Plant Mol. Biol., 49, 427-451.

He, J.X., Gendron, J.M., Sun, Y., Gampala, S.S.L., Gendron, N., Sun, C.Q., Wang, Z.Y. (2005). BZR1 is a transcriptional repressor with dual roles in brassinosteroid homeostasis and growth responses. Science, 307, 1634-1638.

Karakaya, H.C., Tang, Y., Cregan, P.B., Knap, H.T. (2002) Molecular mapping of the fasciation mutation in soybean, Glycine max (Leguminosae). Amer. J. Bot., 89(4), 559-565.

\section{DAUDZGADĪGĀS AIRENES SĀNU DZINUMOS ATŠK̦IRĪGI EKSPRESĒTO GĒNU IDENTIFIKĀCIJA}

Daudzgadīgās airenes mutantam ar palielinātu spēju veidot sānu dzinumus tika salīdzināta gēnu ekspresija galvenajā un sānu dzinumos. Atrasti daži kandidātgēni, kas varētu būt atbildīgi par sānu dzinumu veidošanos. 